\title{
Zinc and Iron Concentration as Affected by Nitrogen Fertilization and Their Localization in Wheat Grain
}

\author{
Bal R. Singh ${ }^{1 *}$, Yadu N. Timsina ${ }^{1}$, Ole C. Lind ${ }^{2}$, Simone Cagno ${ }^{2,3}$ and Koen Janssens ${ }^{3}$ \\ ${ }^{1}$ Faculty of Environmental Sciences and Natural Resource Management, Norwegian University of Life Sciences, Ås, Norway, \\ ${ }^{2}$ Centre of Environmental Radioactivity, Faculty of Environmental Sciences and Natural Resource Management, Norwegian \\ University of Life Sciences, Ås, Norway, ${ }^{3}$ Department of Chemistry, University of Antwerp, Antwerp, Belgium
}

\section{OPEN ACCESS}

Edited by:

Raul Antonio Sperotto,

University of Taquari Valley, Brazil

Reviewed by:

Ümit Barş̧ Kutman,

Gebze Technical University, Turkey

Lourdes Hernandez-Apaolaza,

Universidad Autonoma de Madrid,

Spain

${ }^{*}$ Correspondence: Bal R. Singh

balram.singh@nmbu.no

Specialty section: This article was submitted to Plant Nutrition

a section of the journal

Frontiers in Plant Science

Received: 01 November 2017

Accepted: 22 February 2018

Published: 09 March 2018

Citation:

Singh BR, Timsina $Y N$, Lind $O C$, Cagno S and Janssens K (2018) Zinc and Iron Concentration as Affected by Nitrogen Fertilization and Their Localization in Wheat Grain.

Front. Plant Sci. 9:307.

doi: 10.3389/fpls.2018.00307
Nearly half of the world cereal production comes from soils low or marginal in plant available zinc, leading to unsustainable and poor quality grain production. Therefore, the effects of nitrogen $(\mathrm{N})$ rate and application time on zinc $(\mathrm{Zn})$ and iron $(\mathrm{Fe})$ concentration in wheat grain were investigated. Wheat (Triticum aestivum var. Krabat) was grown in a growth chamber with 8 and $16 \mathrm{~h}$ of day and night periods, respectively. The $\mathrm{N}$ rates were 29, 43, and $57 \mathrm{mg} \mathrm{N} \mathrm{kg}^{-1}$ soil, equivalent to 80,120 , and $160 \mathrm{~kg} \mathrm{~N} \mathrm{ha}^{-1}$. Zinc and Fe were applied at $10 \mathrm{mg} \mathrm{kg}^{-1}$ growth media. In one of the $\mathrm{N}$ treatments, additional $\mathrm{Zn}$ and Fe through foliar spray (6 $\mathrm{mg}$ of $\mathrm{Zn}$ or Fe in $10 \mathrm{ml}$ water /pot) was applied. Micro-analytical localization of $\mathrm{Zn}$ and Fe within grain was performed using scanning macro-X-ray fluorescence (MA-XRF) and laser ablation-inductively coupled plasma-mass spectrometry (LA-ICP-MS). The following data were obtained: grain and straw yield pot $^{-1}, 1000$ grains weight, number of grains $\operatorname{pot}^{-1}$, whole grain protein content, concentration of $\mathrm{Zn}$ and $\mathrm{Fe}$ in the grains. Grain yield increased from 80 to $120 \mathrm{~kg} \mathrm{~N} \mathrm{ha}^{-1}$ rates only and decreased at $160 \mathrm{~kg} \mathrm{~N} \mathrm{ha}^{-1} \mathrm{~g}$. Relatively higher protein content and $\mathrm{Zn}$ and $\mathrm{Fe}$ concentration in the grain were recorded with the split $\mathrm{N}$ application of $160 \mathrm{~kg} \mathrm{~N} \mathrm{ha}^{-1}$. Soil and foliar supply of $\mathrm{Zn}$ and $\mathrm{Fe}\left(\mathrm{Zn}+\mathrm{Fe}_{\mathrm{s}+\mathrm{f}}\right)$, with a single application of $120 \mathrm{~kg} \mathrm{~N}^{-1} \mathrm{~N}$ at sowing, increased the concentration of $\mathrm{Zn}$ by $46 \%$ and of $\mathrm{Fe}$ by $35 \%$, as compared to their growth media application only. Line scans of freshly cut areas of sliced grains showed co-localization of $\mathrm{Zn}$ and Fe within germ, crease and aleurone. We thus conclude that split application of $\mathrm{N}$ at $160 \mathrm{~kg} \mathrm{ha}^{-1}$ at sowing and stem elongation, in combination with soil and foliar application of $\mathrm{Zn}$ and $\mathrm{Fe}$, can be a good agricultural practice to enhance protein content and the $\mathrm{Zn}$ and $\mathrm{Fe}$ concentration in grain.

Keywords: nitrogen application, zinc and iron uptake, zinc and iron distribution in grain, wheat, LA-ICP-MS, MA-XRF

\section{INTRODUCTION}

Cereals are genetically low in $\mathrm{Zn}$ and Fe concentration, with reduced bioavailability (Graham et al., 2001; Cakmak, 2002). About half of the world cereal production come from soils low in plant available Zn (Cakmak, 2002), leading to poor quality of cereal grain with respect to Zn content. The situation is similar, concerning Fe deficiency in cereals. About one third of the developing countries' population and 10\% of Americans and Canadians experience Zn deficiency or are at risk 
of it (Hotz and Brown, 2004), erasing the geographical and political boundaries. Every year $\mathrm{Fe}$ and $\mathrm{Zn}$ deficiency causes deaths of about 800000 children and $2.4 \%$ of global disabilityadjusted life years worldwide (DALYs), while the corresponding value of DALYs for $\mathrm{Zn}$ is $1.9 \%$ (Mutangadura, 2004). DALYs are calculated as the sum of years of life lost (YLLs) and the years lived with disability (YLDs) based on 291 causes and 20 age groups of both sexes. The consumption of white flour made predominantly from endosperm of wheat grain discarding bran in the milling process has even worsened the degree of $\mathrm{Fe}$ and $\mathrm{Zn}$ malnutrition. This is because Fe and $\mathrm{Zn}$ accumulate in higher concentrations in the embryo and aleurone layer than in endosperm of a wheat grain (Šramková et al., 2009; Cakmak et al., 2010). Hence, the consumption of whole grain wheat rather than white wheat flour has been advocated to increase the daily Fe and $\mathrm{Zn}$ intake.

Nitrogen fertilization is known not only to increase wheat grain yield but also to facilitate the uptake of $\mathrm{Fe}$ and $\mathrm{Zn}$ in wheat grain (Cakmak et al., 2010; Shi et al., 2010). The uptake and transport of $\mathrm{Fe}$ and $\mathrm{Zn}$ to grain is probably facilitated by metal chelating compounds (Kutman et al., 2010), such as 2-deoxymugineic acid (DMA) mainly for the translocation of Fe and $\mathrm{Zn}$ from flag leaves to grain in wheat (Barunawati et al., 2013). Kutman et al. (2011) reported that $\mathrm{N}$ nutrition is critical in both the uptake and translocation of $\mathrm{Zn}$ and $\mathrm{Fe}$ to wheat grain and they showed that at high $\mathrm{N}$ rate, nearly $80 \%$ and $60 \%$ of total shoot $\mathrm{Zn}$ and $\mathrm{Fe}$, respectively, were harvested with grain. Improving $\mathrm{N}$ status of plants from low to sufficient resulted in threefold increase in shoot Fe content of wheat plants (Aciksoz et al., 2011) Similarly, Erenoglu et al. (2011) demonstrated that $\mathrm{N}$ is a critical player in the uptake and accumulation of $\mathrm{Zn}$ in plants and thus deserves special attention in biofortification of food crops with $\mathrm{Zn}$. Depending on N supply, Zn remobilization from pre-anthesis sources provided almost all grain $\mathrm{Zn}$, when the $\mathrm{Zn}$ supply was withheld at anthesis (Kutman et al., 2012). Cakmak et al. (2010) found co-localization of protein, Fe and $\mathrm{Zn}$ in embryo and aleurone layer of wheat grain, indicating that the protein rich grains accumulate higher amount of $\mathrm{Zn}$ and Fe in wheat grain. Increasing $\mathrm{Zn}$ and $\mathrm{N}$ supply had a major impact on $\mathrm{Zn}$ accumulation in the endosperm, reaching concentrations higher than the current breeding targets (Persson et al., 2016).

Cakmak et al. (2010) suggested the positive role of soil and foliar applied $\mathrm{Zn}$ and $\mathrm{Fe}$ in increasing respective metal concentrations in durum wheat grain and also claimed that increased activity of $\mathrm{Zn}$ and $\mathrm{Fe}$ in the source (flag leaf and stem) during grain filling could be increased by additional $\mathrm{Zn}$ and $\mathrm{Fe}$ application through soil or by foliar application. Habib (2012) showed that joint Zn-Fe application could increase in grain concentration more than with their separate application. However, the concentrations of $\mathrm{Zn}$ and Fe depend on the size of wheat grains (Velu et al., 2011) and number of grains per spike (Nowack et al., 2008). Haslett et al. (2001) and Timsina (2014) demonstrated the role of phloem transport of $\mathrm{Zn}$ in wheat plants by performing stem girdling, and they showed that ${ }^{65} \mathrm{Zn}$ supplied on upper leaf was transported to lower leaves and root tip.

The concentration of minerals vary within a grain, depending on its portions. For example, wheat endosperm contains about $15 \mathrm{mg} \mathrm{kg}^{-1} \mathrm{Zn}$, while germ and aleurone holds about
$150 \mathrm{mg} \mathrm{kg}^{-1}$ Zn (Šramková et al., 2009). By using laser ablationinductively coupled plasma-mass spectrometry (LA-ICP-MS), Wang et al. (2011) depicted higher concentration of $\mathrm{Zn}$ in the aleurone layer and crease vascular tissue with decreasing gradient of $\mathrm{Zn}$ from crease vascular tissue to endosperm, suggesting that translocation of $\mathrm{Zn}$ toward the endosperm occurred through the crease vascular tissue. Moreover, protein rich grain accumulated higher amount of $\mathrm{Zn}$ and $\mathrm{Fe}$ in wheat than low protein grain (i.e., $\mathrm{Fe}=71 \mathrm{mg} \mathrm{kg}^{-1}$ and $\mathrm{Zn}=57 \mathrm{mg} \mathrm{kg}^{-1}$ vs. Fe $=36 \mathrm{mg} \mathrm{kg}^{-1}$ and $\mathrm{Zn}=30 \mathrm{mg} \mathrm{kg}^{-1}$ ) (Ozturk et al., 2009). This showed that higher protein or nitrogen content favors the accumulation of $\mathrm{Zn}$ and Fe in wheat grain (Peleg et al., 2008; Ozturk et al., 2009; Kutman et al., 2010).

In spite of the available literature on the role of $\mathrm{N}$ on $\mathrm{Zn}$ and Fe uptake by plants, information on the optimum rate and time of $\mathrm{N}$ application, and its effect on $\mathrm{Zn}$ and Fe uptake under varying levels of micronutrients in the soil are scanty. Similarly, the localization of these micronutrients in grains is not fully understood. We hypothesized that (i) $\mathrm{N}$ fertilization increases protein yield components of wheat and the concentration of $\mathrm{Fe}$ and $\mathrm{Zn}$ in grain, (ii) foliar $\mathrm{Zn}$ and $\mathrm{Fe}$ spraying increases their concentration in wheat grain, and (iii) micro-analytical techniques can provide information on the location of $\mathrm{Zn}$ and Fe in wheat grain. To test these hypotheses, we investigated the interactive effect of $\mathrm{N}, \mathrm{Zn}$, and Fe on grain yield, protein content and nutrient concentration in a pot experiment conducted in an environmentally controlled growth chamber. In addition, we investigated the distribution of Fe and $\mathrm{Zn}$ in selected wheat grains by using scanning macro-X-ray fluorescence (MA-XRF) and laser ablation-inductively coupled plasma-mass spectrometry (LA-ICP-MS).

\section{MATERIALS AND METHODS}

\section{Growth Media}

Artificially prepared growth media, according to the OECD 207 guideline (OECD, 1984), were used for growing plants. They consisted of $80 \%$ sand $(<2 \mathrm{~mm}), 10 \%$ peat $(<4 \mathrm{~mm})$, and $10 \%$ kaolin on a dry weight basis. In the absence of sphagnum peat, unfertilized natural peat, produced by Econova Garden AB, Sweden, was used. Air dried peat was sieved through $4 \mathrm{~mm}$ wire mesh and average moisture content was determined by drying nine representative samples in an oven at $105^{\circ} \mathrm{C}$ for $24 \mathrm{~h}$ for the correction of moisture content in peat. Average moisture content varied from 41 to $48 \%$ depending on peat delivery bags. To maintain the $\mathrm{pH}$ of growth media at $6.5 \pm 0.2, \mathrm{CaCO}_{3}$ was mixed at rates from 0.5 to $5 \mathrm{~g}$ per $100 \mathrm{~g}$ growth media and the amount of lime required was calculated from the liming curve obtained. Hand mixed growth media and lime were prepared. The homogeneous growth media mixture was filled in 3-1 plastic pots containing $2015 \mathrm{~g}$ mixture (dry weight) in each pot.

\section{Experimental Design and Fertilizer Rates}

The experiment was set up as a complete randomized factorial design (Table 1). and It consisted of two major treatment factors: $\mathrm{N}$ treatments and $\mathrm{Zn}-\mathrm{Fe}$ treatments. The experiment was further 
TABLE 1 | Design of experiment and rate of fertilization as per treatment.

\begin{tabular}{|c|c|c|c|c|c|}
\hline Zn-Fe-treatments & $\mathrm{N}$ - treatments $\mathrm{N} 1 \mathrm{~N} 80$ & N1N120 & N1N160 & N2N120 & N2N160 \\
\hline \multicolumn{6}{|c|}{ Experiments with soil application of treatment factors ( $N, \mathrm{Zn}$, and $\mathrm{Fe}$ ) } \\
\hline $\mathrm{Zn}$ & NIN80Zn & NIN120Zn & NIN160Zn & N2N120Zn & N2N160Zn \\
\hline $\mathrm{Zn}+\mathrm{Fe}$ & $\mathrm{NIN80} \mathrm{Zn} \mathrm{+} \mathrm{Fe}$ & $\mathrm{NIN120Zn}+\mathrm{Fe}$ & $\mathrm{NIN160Zn}+\mathrm{Fe}$ & $\mathrm{N} 2 \mathrm{~N} 120 \mathrm{Zn}+\mathrm{Fe}$ & $\mathrm{N} 2 \mathrm{~N} 160 \mathrm{Zn}+\mathrm{Fe}$ \\
\hline $\mathrm{Fe}$ & NIN80Fe & NIN120Fe & NIN160Fe & N2N120Fe & N2N160Fe \\
\hline \multicolumn{6}{|c|}{ Experiments with soil plus foliar application of $\mathrm{Zn}$ and Fe } \\
\hline$Z n_{s+f}$ & & 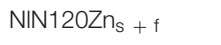 & & $\mathrm{N} 2 \mathrm{~N} 120 Z n_{S}+f$ & \\
\hline $\mathrm{Zn}+\mathrm{Fe}_{\mathrm{S}}+\mathrm{f}$ & & $\mathrm{NIN120}(\mathrm{Zn}+\mathrm{Fe})_{s}+\mathrm{f}$ & & $\mathrm{N} 2 \mathrm{~N} 12 \mathrm{O}(\mathrm{Zn}+\mathrm{Fe})_{\mathrm{s}}+\mathrm{f}$ & \\
\hline $\mathrm{Fe}_{\mathrm{s}+\mathrm{f}}$ & & $\mathrm{NIN} 120 \mathrm{Fe} \mathrm{s}_{+} \mathrm{f}$ & & $\mathrm{N}_{2 N 120 F e}+f$ & \\
\hline
\end{tabular}

Where, N-treatments: Single soil application of N at sowing: N1N80, single application of N at sowing equivalent to $80 \mathrm{~kg}^{\mathrm{N}}$ ha ${ }^{-1}$ mixed wit growth media. N1N120, single application of $\mathrm{N}$ at sowing equivalent to $120 \mathrm{~kg} \mathrm{~N} \mathrm{ha}^{-1}$ mixed with growth media. N1N160, single application of $\mathrm{N}$ equivalent to $160 \mathrm{~kg} N$ ha ${ }^{-1}$ mixed with growth

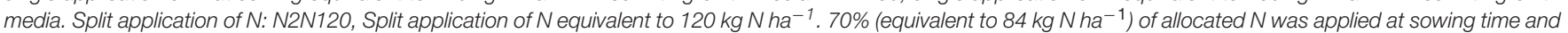

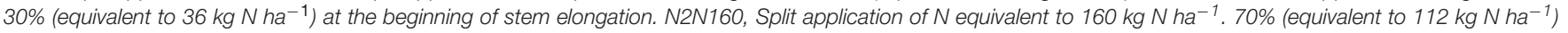

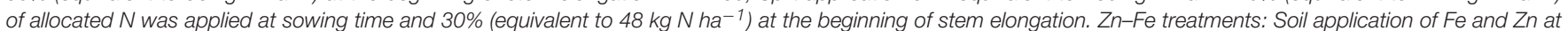

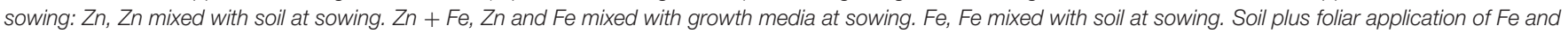

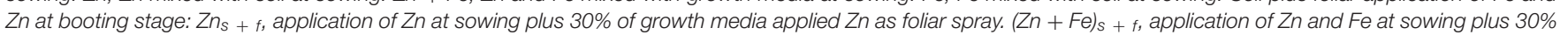
of growth media applied zinc and iron as foliar spray. Fe $+f$, application of Fe at sowing plus $30 \%$ of growth media applied iron as foliar spray.

divided into two groups: (i) experiments with growth media application of all treatment factors $(5 \mathrm{~N}$ treatments $\times 3 \mathrm{Zn}-\mathrm{Fe}$ treatments $=15$ growth media treatments) and (ii) experiments with growth media 1 plus foliar spray of $\mathrm{Zn}$ and $\mathrm{Fe}(2 \mathrm{~N}$ treatments $\times 3 \mathrm{Zn}$-Fe treatments $=6$ growth media plus foliar treatments) (Table 1). Both treatment factors were incorporated into the same experiment to see the combined effect of them. Among the five $\mathrm{N}$-treatments, three were single $\mathrm{N}$ application to growth media before sowing at the rates equivalent to 80 , 120 , and $160 \mathrm{~kg} \mathrm{~N} \mathrm{ha}^{-1}$, and two were split $\mathrm{N}$ applications at the rates equivalent to $120 \mathrm{~kg} \mathrm{~N} \mathrm{ha}^{-1}$ and $160 \mathrm{~kg} \mathrm{~N} \mathrm{ha}^{-1}$. In split application treatments ( $\mathrm{N} 120$ and $\mathrm{N} 160 \mathrm{~kg} \mathrm{~N} \mathrm{ha}^{-1}$ ), $70 \% \mathrm{~N}$ was applied at sowing and $30 \%$ at the stem elongation phase. Similarly, the three $\mathrm{Zn}-\mathrm{Fe}$ treatments included $\mathrm{Zn}, \mathrm{Fe}$, and $\mathrm{Zn}+\mathrm{Fe}$. The rate of $\mathrm{Zn}$ and $\mathrm{Fe}$ application at sowing was $10 \mathrm{mg} \mathrm{kg}^{-1}$ of growth media. Foliar spray of $\mathrm{Zn}$ and $\mathrm{Fe}$ (equal to $6 \mathrm{mg} \mathrm{pot}^{-1}$ ) was made at booting stage in the two $\mathrm{N}$ treatments (single application and split application of $120 \mathrm{~kg} \mathrm{~N} \mathrm{ha}^{-1}$. This was done to assess the effect of foliar spray of $\mathrm{Zn}$ and $\mathrm{Fe}$ on wheat grain yield and $\mathrm{Zn}$ and Fe concentration. Since the artificially made growth media used supplied all nutrients required for plant growth, the need of having a control pot was not felt.

All basic nutrients and the treatment factors $(\mathrm{N}, \mathrm{Zn}$, and $\mathrm{Fe}$ ) were applied in deionized water solution. Powdered calcium carbonate was mixed with growth media to maintain soil $\mathrm{pH}$ at $6.5 \pm 0.2$. The treatment combinations and rates and sources of $\mathrm{N}$ fertilizers and micronutrients are presented in Tables 1, 2, respectively. The solution volume of all nutrients was fixed to $25 \mathrm{ml}$, which was later taken into account while watering the growth media after sowing. All added nutrients and lime were mixed manually to the growth media to get a homogeneous distribution. The second dose of nitrogen in split nitrogen treatments (N2N120 and N2N160), amounting to $30 \%$ of the total $\mathrm{N}$, was added at the beginning of stem elongation and watered immediately, so that $\mathrm{N}$ could spread properly. A handheld sprayer was used. The sprayed solution of $10 \mathrm{ml}$ water per pot contained $6.0 \mathrm{mg}$ of $\mathrm{Zn}$ as zinc sulfate and $6.0 \mathrm{mg}$ of Fe Fe-EDTA mixed with DP-Klebemiddel surfactant with a concentration of $0.5 \mathrm{ml}$ per one liter solution. Spraying was done after complete emergence of flag leaf at booting stage and $10 \mathrm{~mL}$ solution was sprayed several times to ensure that the whole solution was effectively sprayed on plant leaves.

\section{Plant Growth and Harvesting}

Wheat plants were grown in a control growth chamber at about $21^{\circ} \mathrm{C}$. The duration of day and night length was 8 and $16 \mathrm{~h}$, respectively. The source of light was halogen metal halide lamps by POWERSTAR HQI-BT 400W/D. The test plant was a hard red winter wheat variety "Krabat" used by farmers since 2011 which is claimed to be medium early in growth period, high yielding with good agronomical characteristics, medium protein, relatively good disease resistance and baking quality. Twenty seeds were sowed in each pot, which after 1 week were thinned to eight plants. While watering for the first time, the amounts of water contributed by peat and other liquid nutrients were taken into consideration to maintain moisture at $60 \%$ of field capacity throughout the growth period. It was achieved by weighing the pots with soil mixture and plants regularly and adding water to compensate the weight loss.

Plant were harvested at maturity by cutting each spike separately, and these were kept in bags for each pot. After removal of spikes, straw was cut just at the base of first node. Grain and straw yields were recorded after oven drying at $75^{\circ} \mathrm{C}$ for $48 \mathrm{~h}$. Wheat grain and straw were ground in a ball mill (Retsch MM301), with ball and container walls of zirconium to avoid sample contamination. However, for the sake of brevity, only grain yield, protein, $\mathrm{Zn}$, and Fe concentration in grain are reported in this paper.

\section{Chemical Analysis}

Total $\mathrm{N}$ in grain nitrogen was analyzed by dry combustion as described by Bremner and Mulvaney (1982). The whole grain protein (WGP) was obtained by multiplying the total $\mathrm{N}$ by a factor of 5.70 (ISO, 2009). 
TABLE 2 | Rate of treatment factors and basic nutrients applied in soil.

\begin{tabular}{|c|c|c|c|}
\hline Nutrients & Source & Rate & State of application \\
\hline Calcium (Ca) & $\mathrm{CaCO}_{3}$ & $0.5 \mathrm{~g} / \mathrm{kg}$ soil mixture & Powder \\
\hline \multirow[t]{2}{*}{ Nitrogen (N) } & $\mathrm{Ca}\left(\mathrm{NO}_{3}\right)_{2}$ & 80,120 , and $160 \mathrm{~kg} \mathrm{~N} \mathrm{ha}^{-1}$ & Solution \\
\hline & & $\begin{array}{l}70 \text { and } 30 \% \text { of } 120 \text { (i.e., } 84 \text { and } 36 \mathrm{~kg} \mathrm{~N} \mathrm{ha}^{-1} \text { ) and } 160 \text { (i.e., } 112 \text { and } \\
48 \mathrm{~kg} \mathrm{~N} \mathrm{ha}^{-1} \text { ) respectively at sowing and stem elongation. }\end{array}$ & \\
\hline Phosphorus (P) & $\mathrm{Ca}\left(\mathrm{H}_{2} \mathrm{PO}_{4}\right) 2 . \mathrm{aq}$ & $3 \mathrm{~g} \mathrm{P} / \mathrm{l}$ & Solution \\
\hline Potash (K) & $\mathrm{K}_{2} \mathrm{SO}_{4}$ & $12 \mathrm{~g} \mathrm{~K} / \mathrm{I}$ & Solution \\
\hline Magnesium (Mg) & $\mathrm{MgSO}_{4} .7 \mathrm{H}_{2} \mathrm{O}$ & $12.5 \mathrm{~g} \mathrm{st} / \mathrm{l}$ & Solution \\
\hline Iron (Fe) & $\mathrm{Fe}$-EDTA $\left(\mathrm{C}_{1} \mathrm{H}_{12} \mathrm{FeN}_{2} \mathrm{NaO}_{8} \cdot \mathrm{H}_{2} \mathrm{O}\right)$ & 10 mg Fe/kg soil & Solution \\
\hline Manganese (Mn) & $\mathrm{MnSO}_{4} \cdot 4 \mathrm{H}_{2} \mathrm{O}$ & $2.50 \mathrm{~g} \mathrm{st} / \mathrm{l}$ & Solution \\
\hline Copper (Cu) & $\mathrm{CuSO}_{4} \cdot 2 \mathrm{H}_{2} \mathrm{O}$ & $2.50 \mathrm{~g} \mathrm{st} / \mathrm{l}$ & Solution \\
\hline Molybdenium (Mo) & $\left(\mathrm{NH}_{4}\right) 6 \mathrm{Mo} \mathrm{O}_{22} \cdot 4 \mathrm{H}_{2} \mathrm{O}$ & $0.05 \mathrm{~g} \mathrm{st} / \mathrm{l}$ & Solution \\
\hline Boron (B) & $\mathrm{Na}_{2} \mathrm{~B}_{4} \mathrm{O} 7.10 \mathrm{H}_{2} \mathrm{O}$ & $0.25 \mathrm{~g} \mathrm{st} / \mathrm{l}$ & Solution \\
\hline Zinc (Zn) & $\mathrm{ZnSO}_{4} \cdot 7 \mathrm{H}_{2} \mathrm{O}$ & 10 mg Zn/kg soil & Solution \\
\hline
\end{tabular}

All solutions were added to growth media before sowing at volume $25 \mathrm{ml}$. Rows with bold letters represent for treatment factors.

About $0.2 \mathrm{~g}$ of ground wheat flour was digested in $5 \mathrm{ml}$ conc. $\mathrm{HNO}_{3}$ for about $2 \mathrm{~h}$ in ultra clave microwave reactor (MLS-MILESTONE, ultra-CLAVE III) at $250^{\circ} \mathrm{C}$ and at $160 \mathrm{bar}$ pressure. The digested samples were diluted to $50 \mathrm{ml}$ by adding double de-ionized water (B-pure, Barnstead). Three Standard Reference Materials (SRM) (SRM1567a wheat flour) and 5 method blanks (5 $\mathrm{ml} \mathrm{HNO}_{3}$ solution) were also digested along with grain samples. Concentrations of $\mathrm{Fe}$ and $\mathrm{Zn}$ were analyzed by an inductively coupled plasma optical emission spectrometer (ICP-OES, Perkin-Elmer Optima 5300 DV) in wheat samples, SRM, and method blanks.

The lower detection limits (LOD's) and lower quantification limits (LOQ's) were determined for the concentration of Fe and $\mathrm{Zn}$ in the method. Measured concentrations of $\mathrm{Fe}$ and $\mathrm{Zn}$ in all samples were higher than LOD's (Average of blanks plus 3 times the SD) and LOQs (Average of blanks plus 10 times the SD). The accuracy of analytical method was determined by the analysis of three replicates of standard reference materials (SRMs 1567a wheat flour). The measured concentrations of Fe and $\mathrm{Zn}$ in SRMs were in accordance with the certified concentration limits and the RSD was $<5 \%$.

\section{Localization of Fe and $\mathrm{Zn}$ in Wheat Grain}

Six selected wheat grains from different treatments containing relatively high $\mathrm{Zn}(42-99 \mathrm{mg} / \mathrm{kg})$ and $\mathrm{Fe}(44-115 \mathrm{mg} / \mathrm{kg})$ concentration were used. These grain samples were collected from different pots showing higher $\mathrm{Zn}$ and Fe concentration and mostly from foliar experiment and thus here the effect of $\mathrm{N}$ on $\mathrm{Zn}$ and Fe location was not clearly investigated. At first, the Environmental scanning electron microscope with dispersive X-ray spectrometry (ESEM-EDS) technique, available at the Norwegian University of Life Sciences (NMBU), Norway, was used for observation of grain morphology and element distribution. However, the limit of detection of ESEM-EDS $(0.1 \% \mathrm{w} / \mathrm{w})$ was not sufficiently low to detect and quantify $\mathrm{Zn}$ and $\mathrm{Fe}$ in the expected concentrations. For trace element 2D distribution analysis, Scanning macro- X-ray fluorescence (MA-XRF) and laser ablation-inductively coupled plasma-mass spectrometry (LA-ICP-MS) were performed at the University of Antwerp, Belgium.

Each seed was sliced in two parts. Slicing of grains was done with a razor blade that was cleaned with ethanol prior to use. The half grains were measured with no additional sample preparation. In the case of MA-XRF, they were mounted by means of adhesive tape on a diapositive frame positioned vertically on sample holder. The measurement, after verifying the sample-sourcedetector distance, was performed in an entirely non-invasive way.

In the case of LA-ICP-MS, they were introduced mounted horizontally on plasticine on the floor of the sample chamber, which was closed and purged. Detailed photographs of the surface were acquired by means of the instrument software, and the line profiles were drawn and ablated on the basis of those.

MA-XRF was performed using a non-commercial selfassembled Scanning macro- X-ray fluorescence (XRF), with the setup named instrument C (Alfeld et al., 2011). The elemental maps were recorded with a step size of $25-\mu \mathrm{m}$ and dwell time of $400 \mathrm{~ms}$ per point with tube settings of $50 \mathrm{kV}$ and $1.0 \mathrm{~mA}(35 \mathrm{~W})$. The beam size at the focal point was approximately $50 \mu \mathrm{m}$. XRF maps were obtained for each element detectable in the grains. The most relevant elements were $\mathrm{Fe}, \mathrm{Zn}$, and $\mathrm{K}$, whose distribution is shown in Figure 6. For a more detailed analysis of these elements and their co-occurrence in the grain, the following technique was used.

LA-ICP-MS was performed with a New Wave NWR193 ArF excimer laser and a Varian 7700 quadrupole ICP-MS. The ablation of sample was performed in helium gas $(\mathrm{He})$ and transported to the plasma in argon gas (Ar). The flow rate was set to $0.4 \mathrm{l} / \mathrm{min}$ for carrier gas and $0.7 \mathrm{l} / \mathrm{min}$ for makeup gas. The forward power was set to 1350 watt. The line scan was executed at the speed of $10 \mu \mathrm{m} / \mathrm{s}$ with dimension more than $3 \mathrm{~mm}$ length and $100 \mu \mathrm{m}$ beam diameter. The repetition rate of scan was $20 \mathrm{~Hz}$ at $90 \%$ energy capacity. The fluence was maintained at approximately $8 \mathrm{~J} / \mathrm{cm}^{2}$. The laser warm up at the beginning of scan lasted until $20 \mathrm{~s}$ and washout begin after about $290 \mathrm{~s}$ and lasting until $350 \mathrm{~s}$. This generated gross 
element counts, which were further refined in the following way. Background counts were collected along the scan line before and after the wheat grain (which was located in the middle of a scan line). Net counts were determined by subtracting from the gross counts the average background counts (after removal of outliers) for each element (K, Fe, $\mathrm{Zn}$ ). Finally, the normalized counts of $\mathrm{Zn}$ and $\mathrm{Fe}$ were determined by dividing their respective net counts with net counts for K. Potassium, $\left({ }^{39} \mathrm{~K}\right)$ was used as the normalizing element since it occurs in a more evenly distributed way throughout the grain, and particularly in the crease, as made visible by MA-XRF in Figure 6D. The use of K-normalized counts for Fe and Zn, helps evidencing any real increase of either element in spots/areas of the grain, independently from total ion count and surface/positioning effects.

\section{Statistical Analysis}

The analysis of variance (ANOVA) was performed by twoway ANOVA and the relations between variables were analyzed by regression model using Minitab 16. During the regression analysis, data for independent variables were centered on their average value when necessary. For centering of data, each observed value was subtracted from the average of the respective variable. The comparison between all treatments, considering the interaction of treatment factors and main effects of N- and $\mathrm{Zn}$ $\mathrm{Fe}$ - treatments, was carried out by Tukey comparison. In all cases, data were analyzed considering $5 \%$ level of significance $(p=0.05)$.

\section{RESULTS}

\section{Grain Yield}

The grain yield pot $^{-1}$ increased while increasing $\mathrm{N}$ rate from 80 to $120 \mathrm{~kg} \mathrm{~N} \mathrm{ha}^{-1}$, but decreased when $\mathrm{N}$ was increased to $160 \mathrm{~kg} \mathrm{~N} \mathrm{ha}{ }^{-1}$. A similar trend was also observed for split application of $\mathrm{N}$ from 120 to $160 \mathrm{~kg} \mathrm{~N} \mathrm{ha}^{-1}$. The single application of $120 \mathrm{~kg} \mathrm{~N} \mathrm{ha}^{-1}$ at sowing (N1N120) and split application of $160 \mathrm{~kg} \mathrm{~N} \mathrm{ha}^{-1}$ at sowing and stem elongation (N2N160) resulted in the highest yield (Figure 1). Likewise, the growth media application of $\mathrm{Zn}$ produced higher yield than growth media applied $\mathrm{Fe}$ and $\mathrm{Zn}+\mathrm{Fe}$, particularly at the application rate of $160 \mathrm{~kg} \mathrm{~N} \mathrm{ha}^{-1}$ at sowing (Figure 1).

The growth media plus foliar application $\left(\mathrm{Zn}_{\mathrm{s}+\mathrm{f}}\right.$ or $\left.\mathrm{Fe}_{\mathrm{s}+\mathrm{f}}\right)$ for $\mathrm{Zn}$ and $\mathrm{Fe}$, single or together, increased the grain yield in comparison to their growth media application at sowing. The single application (N1N120) of $120 \mathrm{~kg} \mathrm{~N} \mathrm{ha}^{-1}$ resulted in significantly higher yield $\left(3.02 \pm 0.04 \mathrm{~g} \mathrm{pot}^{-1}\right)$ than the split application $(\mathrm{N} 2 \mathrm{~N} 120)$ of $120 \mathrm{~kg} \mathrm{~N} \mathrm{ha}^{-1}\left(2.87 \pm 0.04 \mathrm{~g} \mathrm{pot}^{-1}\right)$ (Table 3) in all combinations of $\mathrm{Zn}$ and Fe, except for growth meida plus foliar spray of $\mathrm{Zn}$. The $\mathrm{Zn}$-Fe treatment $(\mathrm{Zn}+\mathrm{Fe})$ did not show a significant difference in mean grain yield for experiments with growth media 1 plus foliar application $\left(\mathrm{Zn}+\mathrm{Fe}_{\mathrm{s}}+_{\mathrm{f}}\right)$ of $\mathrm{Zn}$ and $\mathrm{Fe}(p=0.107)$.

\section{Whole Grain Protein (WGP)}

The growth media and foliar application $\left(\mathrm{Zn}_{\mathrm{s}+\mathrm{f}}\right.$ or $\left.\mathrm{Fe}_{\mathrm{s}+\mathrm{f}}\right)$ resulted in significantly higher wheat grain protein (WGP) as compared to growth media application ( $\mathrm{Zn}$ or Fe) $(p=0.021)$ at single as well as split $\mathrm{N}$ equivalent to $120 \mathrm{~kg} \mathrm{~N}^{-1}$ (Table 4). Irrespective of $\mathrm{N}$ treatments, average increase of WGP for growth media 1 plus foliar application of $\mathrm{Zn}+\mathrm{Fe}_{\mathrm{s}}+\mathrm{f}, \mathrm{Zn}_{\mathrm{s}}+\mathrm{f}$ and Fs + fe was $8.4,6.5$, and $7 \%$ as compared to their growth media applied rate $(\mathrm{Zn}+\mathrm{Fe}, \mathrm{Zn}, \mathrm{Fe})$. Among all treatments, the growth media plus foliar application of $\mathrm{Zn}+\mathrm{Fe}$ at split application of $120 \mathrm{~kg} \mathrm{~N} \mathrm{ha}^{-1}\left(\mathrm{Zn}+\mathrm{Fe}_{\mathrm{s}}+\mathrm{f}\right.$ at N2N120) produced the highest protein rich grains $(8.96 \pm 0.133 \%)$, suggesting that split $\mathrm{N}$ application is a better method to achieve higher protein in wheat grain. Zinc in combination with single growth media application of $120 \mathrm{~kg} \mathrm{~N} \mathrm{ha}^{-1}$ (Zn at N1N120) gave the lowest protein content $(7.95 \pm 0.06 \%)$ (Table 4).

\section{Iron Concentration in Wheat Grain}

Iron concentration in grain was significantly affected by growth media supplied $\mathrm{N}(p<0.001)$. The increasing rate of $\mathrm{N}$ from N1N80 to N1N160) resulted in significantly higher $\mathrm{Fe}$ concentration in grain when $\mathrm{Fe}$ was applied alone (Figure 2).

The growth media and foliar application $\left(\mathrm{Fe}_{\mathrm{s}}+\mathrm{f}\right.$ and $\left.\mathrm{Zn}+\mathrm{Fe}_{\mathrm{s}}+\mathrm{f}\right)$ of $\mathrm{Fe}$ increased the $\mathrm{Fe}-$ concentration in wheat grain significantly $(p<0.001)$ as compared to their growth media applied rate $(\mathrm{Fe}$ and $\mathrm{Zn}+\mathrm{Fe})$. Both growth media $(\mathrm{Zn}+\mathrm{Fe})$ or growth media plus foliar application $\left(\mathrm{Zn}+\mathrm{Fe}_{\mathrm{s}}+\mathrm{f}\right)$ of $\mathrm{Zn}+\mathrm{Fe}$ showed higher Fe- concentration in wheat grain, but a significantly higher Fe-concentration was achieved only with $\mathrm{Zn}+\mathrm{Fe}_{\mathrm{s}}+\mathrm{f}$ at N1N120 (Figure 3).

\section{Zinc Concentration in Wheat Grain}

Grain Zn-concentration responded significantly to the main effect of $\mathrm{N}$-treatment $(p<0.001)$. When $\mathrm{N}$ rate at sowing increases from 80 to $120 \mathrm{~kg} \mathrm{~N}^{-1}$ (N1N80 to N1N120), the concentration of $\mathrm{Zn}$ in grain tends to decrease (Figure 4). For instance, single application of $120 \mathrm{~kg} \mathrm{~N} \mathrm{ha}^{-1}$ (N1N120) and split application of $160 \mathrm{~kg} \mathrm{~N} \mathrm{ha}^{-1}$ (N2N120) showed about $10 \%$ less $\mathrm{Zn}$ as compared to single application of 80 and $160 \mathrm{~kg} \mathrm{~N} \mathrm{ha}^{-1}$ (N1N80 or N1N160). All other combinations of treatments showed generally the same $\mathrm{Zn}$ concentration.

In the experiments with growth media plus foliar spray of $\mathrm{Zn}$ and $\mathrm{Fe}\left(\mathrm{Zn}_{\mathrm{s}}+\mathrm{f}\right.$ and $\left.\mathrm{Zn}+\mathrm{Fe}_{\mathrm{s}}+\mathrm{f}\right), \mathrm{Zn}$ - concentration in wheat grain increased significantly $(p<0.01)$, but was not affected by $\mathrm{N}$ - treatments and the interaction between $\mathrm{N}$ - and $\mathrm{Zn}-\mathrm{Fe}$ treatments. The increase in the grain $\mathrm{Zn}$-concentration in foliar sprayed treatments $\left(\mathrm{Zn}_{\mathrm{s}}+\mathrm{f}\right.$ and $\left.\mathrm{Zn}+\mathrm{Fe}_{\mathrm{s}}+\mathrm{f}\right)$ was higher than with $\mathrm{Zn}$ or $\mathrm{Zn}+\mathrm{Fe}$ treatments at N1N120 or N2N120, but a significantly higher $\mathrm{Zn}$ - concentration was achieved only with $\mathrm{Zn}+\mathrm{Fe}_{\mathrm{s}+\mathrm{f}}$ at N1N120 (Figure 5).

\section{Relationship Between Fe- and Zn- Concentration and Grain Yield Parameters}

A multiple linear regression including all measurements for 84 growth pots provided a valid relationship $(p<0.001)$ between $\mathrm{Fe}$ concentration in grain and the total grain weight (TGW), number 


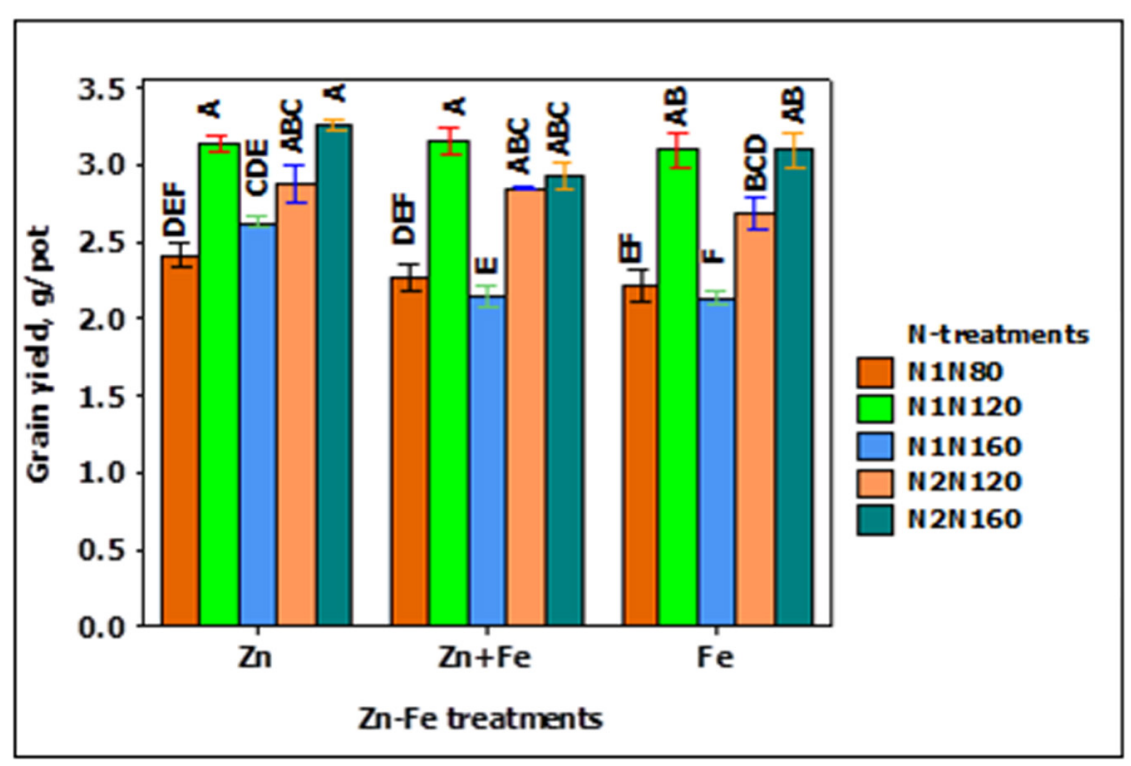

FIGURE 1 | Grain yield at N when Zn, Zn + Fe, and Fe applied to growth media at sowing. N1 and N2 for single and split N. 80, 120, and 160 stand for rate of N in $\mathrm{kg} \mathrm{ha}^{-1}$. Bars with same alphabet at head are not significantly different at $5 \%$ level of significance.

TABLE 3 | Mean \pm 1 SE grain yield $\left(\mathrm{g} \mathrm{pot}^{-1}\right)$ at experiment with growth media plus foliar application of Zn and Fe.

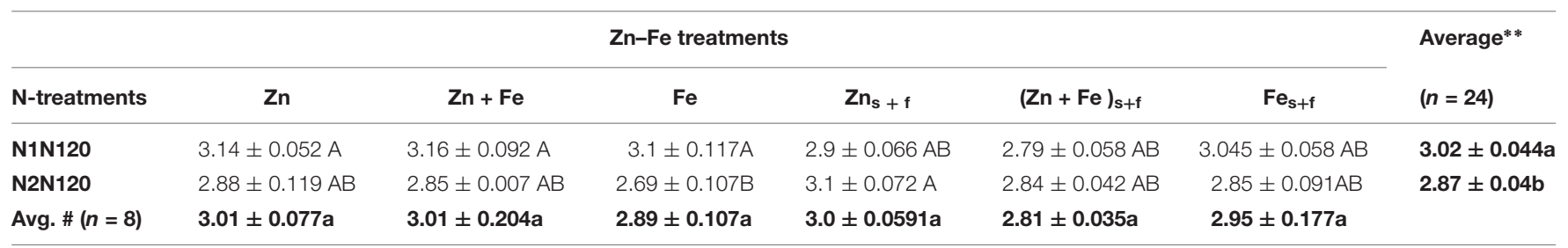

** Significant at $p=0.01$; \#Not significant at $p=0.05$; Avg., Average; Treatment means \pm 1 SE $(n=4)$ followed by same upper case alphabet are not significantly different for $\mathrm{N}-\times \mathrm{Zn}-\mathrm{Fe}$-treatments. Average means followed by same lower case alphabet are not significantly different for respective $\mathrm{N}$ - or $\mathrm{Zn}-\mathrm{Fe}$ - treatments. Tukey comparison was performed at $5 \%$ level of significance. N1 and N2 stand for single and split application of N. N120 stands for growth media application of $120 \mathrm{~kg} N$ ha ${ }^{-1}$. Zn, Zn $+F e$ and Fe without suffix for growth media application of Zn-Fe- treatments and with suffix's $+f^{\prime}$ for growth media plus foliar application.

TABLE 4 | Mean \pm 1 SE $(n=4)$ whole grain protein (\%) in wheat grains at experiment with growth media plus foliar application of $\mathrm{Zn}$ and Fe.

\begin{tabular}{|c|c|c|c|c|c|c|c|}
\hline \multicolumn{7}{|c|}{$\mathrm{Zn}-\mathrm{Fe}$ treatments } & \multirow{2}{*}{$\begin{array}{l}\text { Average * } \\
(n=24)\end{array}$} \\
\hline $\mathrm{N}$-treatments & $\mathrm{Zn}$ & $\mathrm{Zn}+\mathrm{Fe}$ & $\mathrm{Fe}$ & $Z n_{s+f}$ & $(\mathrm{Zn}+\mathrm{Fe})_{\mathrm{s}+\mathrm{f}}$ & $\mathrm{Fe}_{\mathrm{s}+\mathrm{f}}$ & \\
\hline N1N120 & $7.9 \pm 0.108 \mathrm{C}$ & $8.13 \pm 0.101 \mathrm{BC}$ & $8.0 \pm 0.042 \mathrm{BC}$ & 3.51. \pm 0.1 (BAB & $8.88 \pm 0.0 .122 \mathrm{~A}$ & $8.46 \pm 0.096 \mathrm{AB}$ & $8.315 \pm 0.0788 b$ \\
\hline N2N120 & $8.01 \pm 0.061 \mathrm{BC}$ & $8.326 \pm 0.108 \mathrm{BC}$ & $8.21 \pm 0.154 \mathrm{BC}$ & S. $44 \pm 0.114 \mathrm{ABC}$ & $8.956 \pm 0.133 \mathrm{~A}$ & $8.87 \pm 0.131 \mathrm{~A}$ & $8.468 \pm 0.0836 a$ \\
\hline Avg. ${ }^{* * *}(n=8)$ & $7.95 \pm 0.061 d$ & $8.23 \pm 0.07 \mathrm{Scd}$ & $8.11 \pm 0.084 d$ & $8.48 \pm 0.073 b c$ & $8.92 \pm 0.085 a$ & $8.67 \pm 0.108 a b$ & \\
\hline
\end{tabular}

*** Significant at $p=0.001$; *significant at $p=0.05$; Avg., Average. The significance of letters after means and treatments are explained in Table 3.

of grains pot $^{-1}$ and grain Fe-uptake (Equation 1) rather than with a single variable. The coefficient of TGW and number of grains pot $^{-1}$ were negative, but positive for grain Fe-uptake. It indicated that grain Fe-concentration had a tendency to increase when total $\mathrm{Fe}$-uptake in the grain increased but tend to lower with increase in grain yield parameters: TGW and number of grains $\operatorname{pot}^{-1}$.

Grain Fe - concentration $\left(\mathrm{mg} \mathrm{kg}^{-1}\right)=69.89-0.96 \mathrm{TGW}$ (g) -0.321 No. of grains pot ${ }^{-1}+261.46$ Grain Fe - uptake grain $\left(\mathrm{mg} \mathrm{pot}^{-1}\right)$ $p<0.001$ (for regression model, No. of grains pot $^{-1}$, Grain Fe- uptake); $p>0.05$ for TGW;

Similarly, a regression analysis of $\mathrm{Zn}$ concentration in grain with TGW, number of grains $\operatorname{pot}^{-1}$ and grain $\mathrm{Fe}$ uptake in together showed a significant relation $(p<0.01)$ (Equation 2). The regression model defined about $72 \%$ of the variability in the grain $\mathrm{Zn}$ - concentration indicating the role of other variables in its determination. Positive coefficients of TGW and total Zn- uptake in grain indicated that grain $\mathrm{Zn}$ concentration tend to increase with these factors and negative coefficient for number of grains $\operatorname{pot}^{-1}$ hint for decrease in 


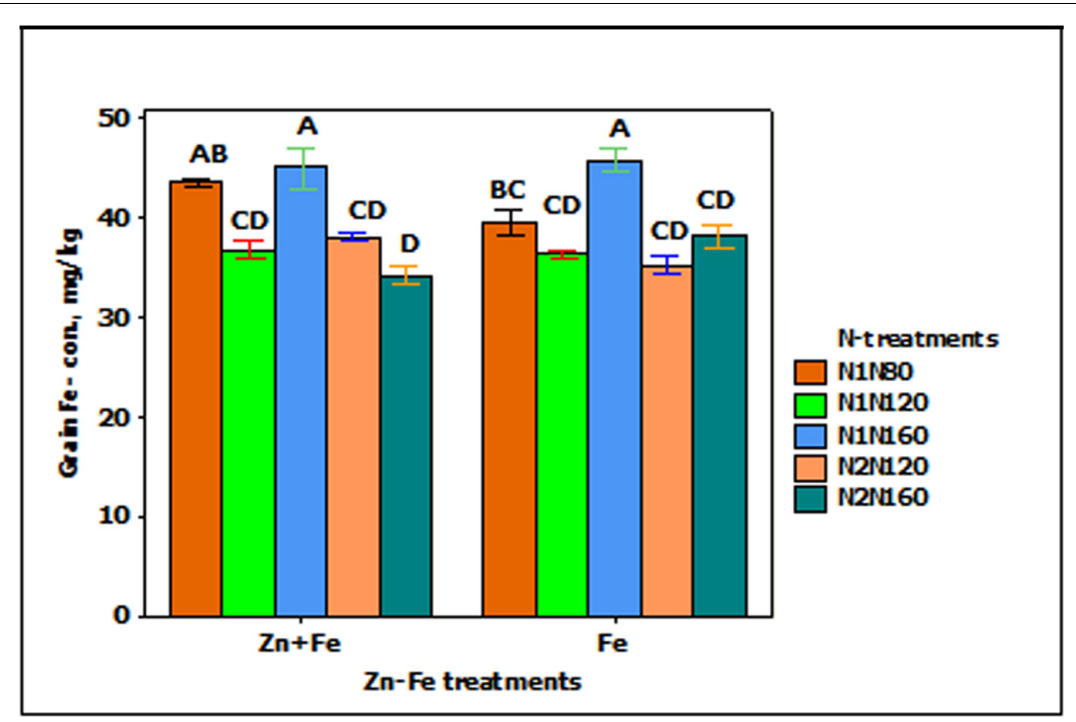

FIGURE 2 | Mean \pm 1 SE $(n=4)$ bar plot for the responses of grain Fe- concentration at N-treatments when $\mathrm{Zn}+\mathrm{Fe}$ and Fe applied to growth media at sowing. N1 and $\mathrm{N} 2$ for single and split N. 80, 120, and 160 stand for rate of $\mathrm{N}$ in $\mathrm{kg} \mathrm{ha}^{-1}$. Bars with same alphabet at head are not significantly different at $5 \%$ level of significance.

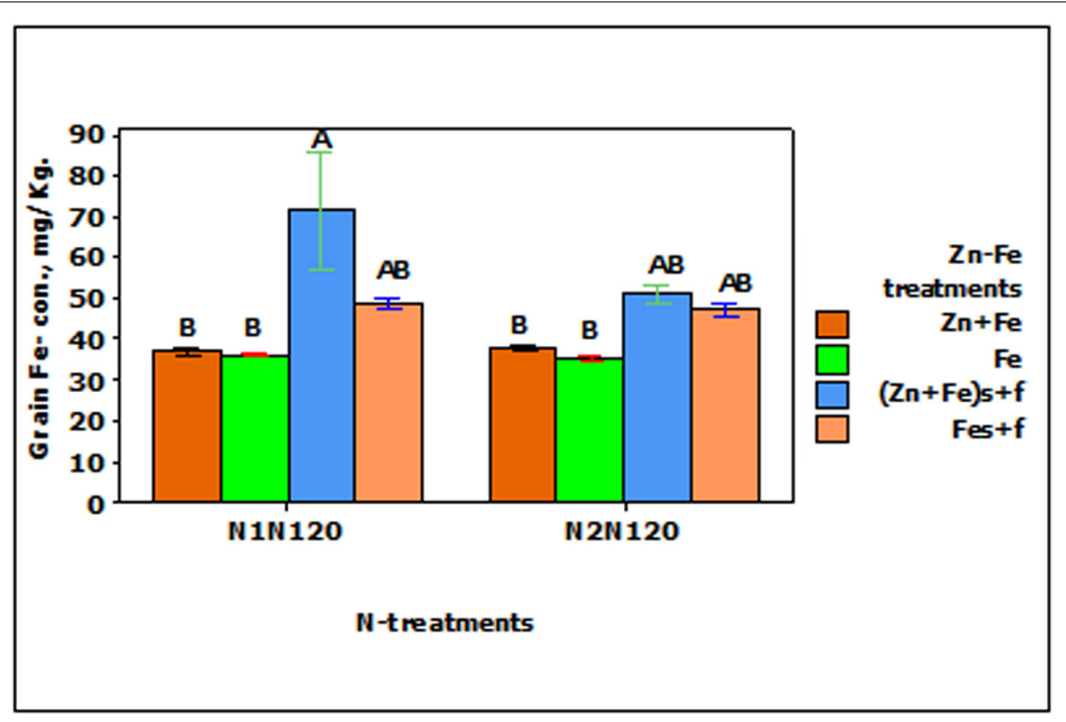

FIGURE 3 | Mean \pm 1 SE $(n=4)$ bar plot of grain Fe- concentration for the effect of Zn-Fe- treatments. N1 and N2 stand for single and split application of N. N120 stands for $120 \mathrm{~kg} \mathrm{~N} \mathrm{ha}^{-1}$. Zn + Fe and Fe without suffix for growth media application and with suffix $s+f$ for growth media plus foliar application. Bars with same alphabet at head are not significantly different at $5 \%$ level of significance.

grain $\mathrm{Zn}$ - concentration when number of grains pot $^{-1}$ tended to increase.

Grain $\mathrm{Zn}-$ concentration $\left(\mathrm{mg} \mathrm{kg}^{-1}\right)=45.625-0.646 \mathrm{TGW}$ (g) -0.211 No. of grains pot ${ }^{-1}+120.98$ Grain $\mathrm{Zn}-$ uptake (content) in grain $\left(\mathrm{mg} \mathrm{pot}^{-1}\right)$

$p<0.001$ (for regression model, Grain Zn- uptake; No. of grains pot $\left.^{-1}\right) ; p>0.05$ (for TGW).

\section{Localization of $\mathrm{Zn}$ and $\mathrm{Fe}$ in Wheat Grain}

Element distribution map of half wheat grains generated by the MA-XRF are shown in Figure 6. Relatively bright spots in the maps represent higher $\mathrm{X}$ - ray signal from the respective elements. This signal is influenced by the element concentration in the sample, among other factors. However, the analyzed surfaces of grains were slightly irregular and this gives rise to somewhat hazy depiction of the element distribution.

In the MA-XRF maps, it is obvious that $\mathrm{Fe}$ and $\mathrm{Zn}$ concentrations are rather variable inside the wheat grain. 


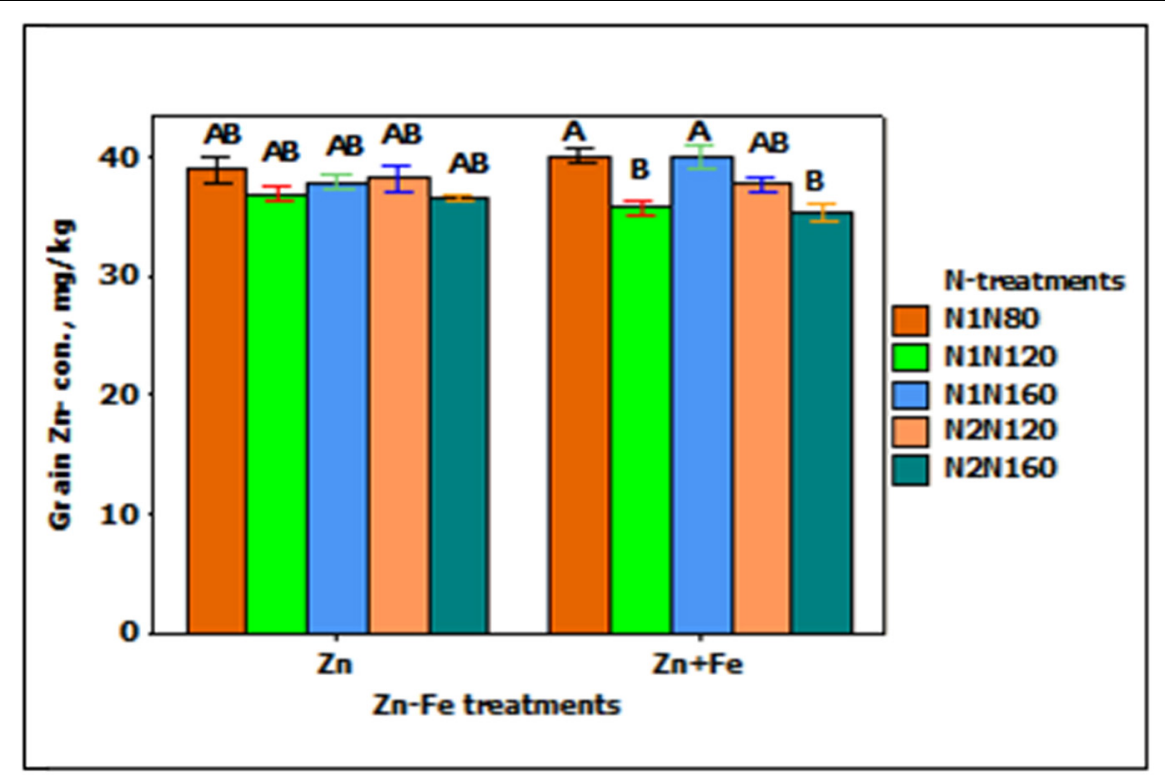

FIGURE 4 | Mean \pm 1 SE $(n=4)$ bar plot for the responses of grain Zn- concentration at N-treatments when Zn and Zn + Fe applied to growth media at sowing. N1 and N2 for single and split N. 80, 120, and 160 stand for rate of N in kg ha ${ }^{-1}$. Bars with same alphabet at head are not significantly different at $5 \%$ level of significance.

FIGURE 5 | Mean \pm 1 SE $(n=4)$ bar plot of grain Zn- concentration for the effect of Zn-Fe- treatments. N1 and N2, respectively stand for single and split application of N. N120 stands for $120 \mathrm{~kg} \mathrm{~N}$ ha ${ }^{-1}$. Zn and Zn + Fe without suffix for growth media application and with suffix $s+f$ for growth media plus foliar application. Bars with same alphabet at head are not significantly different at $5 \%$ level of significance.

However, Fe and $\mathrm{Zn}$ seem to have similar patterns throughout all grains. Iron concentrated mainly in embryo and to some extent along the aleurone layer in the crease area (Figure 6B). Zn appears to be present in the embryo and along crease just outside the endosperm (Figure 6C).

LA-ICP-MS was performed on three out of the six samples that were analyzed by MA-XRF. LA-ICP-MS was used to obtain normalized signals for Fe and $\mathrm{Zn}$ along a well-defined line profile transversally across the grains (Figure 7). Generally, the profiles for both elements appear to vary in a similar fashion, confirming their co-localization. The normalized $\mathrm{Zn}$ and Fe counts clearly peaked at well-defined points. Higher signals of both elements were found at both ends of the grain and, for $\mathrm{Zn}$ only, at the embryo-aleurone interface in the middle of the grain. The 


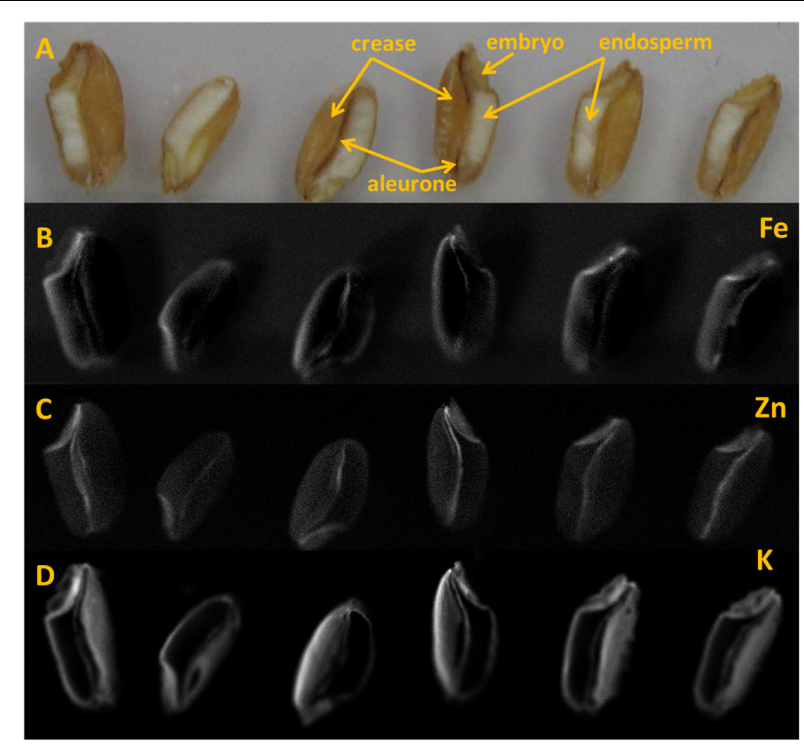

FIGURE 6 | Half wheat grains analyzed under MA-XRF Instrument C.

(A) Position of wheat grains subjected to MA-XRF. (B-D) Element distribution maps (1400 $\times 400$ pixels) of wheat grains. (B) Iron, (C) Zinc and

(D) Potassium.

lowest signals for both elements were encountered within the endosperm. Higher normalized signals can be seen for Fe than for $\mathrm{Zn}$ at both ends of the grain, generally associated with bran.

\section{DISCUSSION}

\section{Grain Yield}

Among $\mathrm{N}$ treatments, grain yield increased from the $\mathrm{N}$ rate of $80 \mathrm{~kg} \mathrm{~N} \mathrm{ha}^{-1}(\mathrm{~N} 1 \mathrm{~N} 80)$ to the $\mathrm{N}$ rate of $120 \mathrm{~kg} \mathrm{~N} \mathrm{ha}^{-1}(\mathrm{~N}-$ treatments: N1N120 and N2N120) but it decreased at the highest $\mathrm{N}$ rate of $160 \mathrm{~kg} \mathrm{~N} \mathrm{ha}^{-1}$. This suggested positive yield response to increasing $\mathrm{N}$ application rate up to a definite rate only (Marino et al., 2009; Abedi et al., 2011) and decline beyond this level. Split application of $160 \mathrm{~kg} \mathrm{~N} \mathrm{ha}^{-1}$ (70\% at sowing and $30 \%$ at stem elongation) produced higher grain yield than at split application of $120 \mathrm{~kg} \mathrm{~N} \mathrm{ha}^{-1}$. Reduction in grain yield at higher $\mathrm{N}$ rate may be associated to dilution of $\mathrm{Zn}$ and Fe, thus limiting their supply. As pointed out by Kutman et al. (2011), significant reduction in grain yield was caused by the high $\mathrm{N}$ treatment under the discontinued $\mathrm{Zn}$ regime. Dilution of $\mathrm{Zn}$ may have affected grain yield by impairing the reproductive development (Cakmak and Engels, 1999). It is likely that the reproductive development in later spikes was negatively affected by poor supply of $\mathrm{Zn}$ (Kutman et al., 2011).

Grain yield was significantly higher for growth media application of $\mathrm{Zn}$ than growth media applied $\mathrm{Fe}$ or $\mathrm{Fe}+\mathrm{Zn}$. The results are in line with Silspour (2007) and Nadim et al. (2012). Nadim et al. (2012) recorded significant increase in grain yield with soil applied $\mathrm{Zn}$ (in the form of $\mathrm{ZnSO}_{4}$ ) in comparison with soil applied Fe. The effect of $\mathrm{N}$ on grain yield and the increase in grain yield for growth media applied $\mathrm{Zn}$ was also associated with the increased number of grain $\operatorname{pot}^{-1}$ (data not

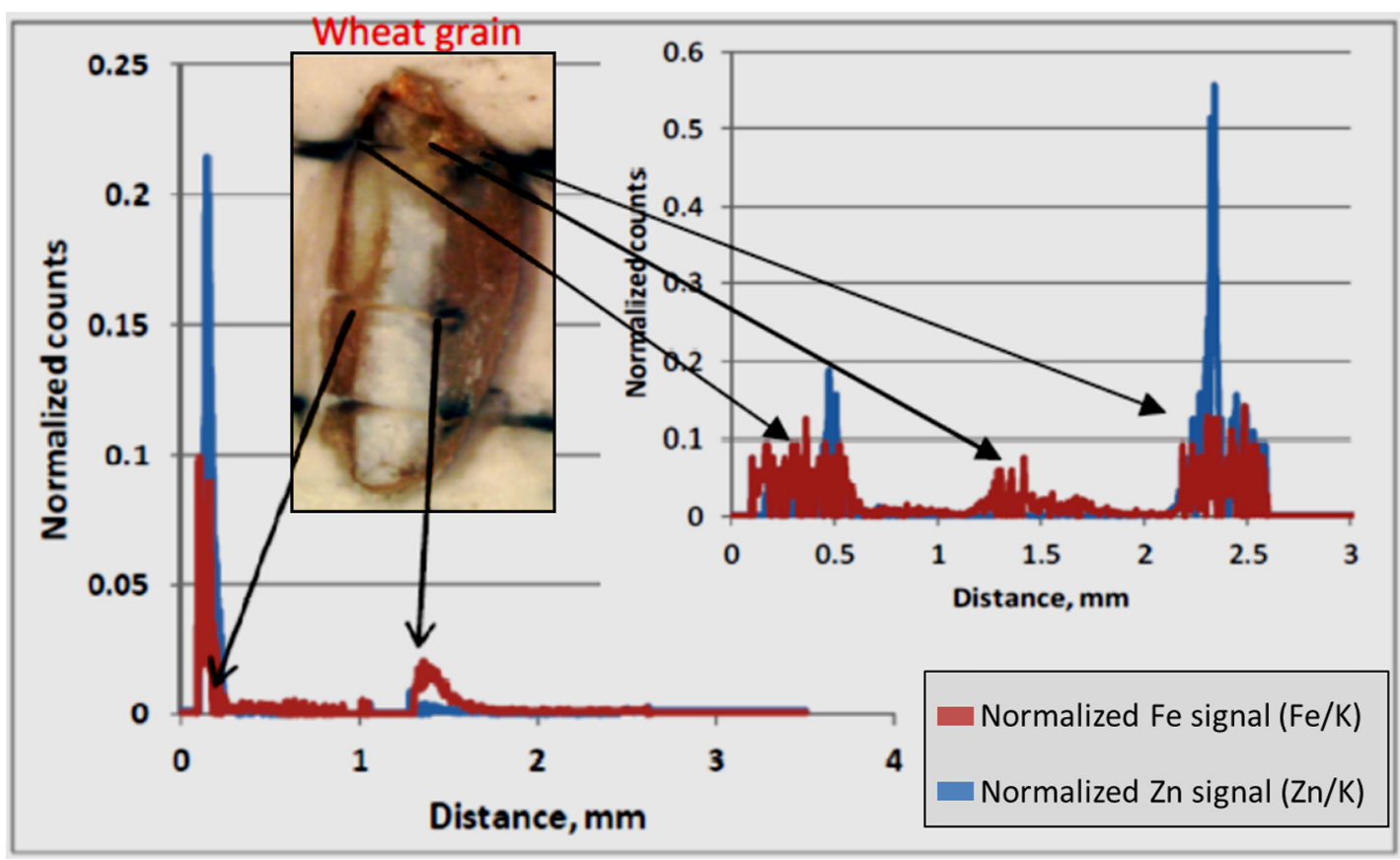

FIGURE 7 | LA-ICP-MS Normalized counts along scan profiles. Normalized counts represent the relative count intensity of Zn and Fe with respect to K. The signals for $\mathrm{Zn}$ and Fe for two scan lines are shown. The arrows indicate approximate location for elevated $\mathrm{Zn}$ and Fe signals in the grain fall on scan line. The white part in the picture of the wheat grain is the endosperm and bran is on either sides of endosperm. The embryo is at the top the grain. The bran at right hand side of endosperm is the crease. 
shown). Kutman et al. (2012) showed that the increase in the grain yield due to improved $\mathrm{N}$ and $\mathrm{Zn}$ supply was parallel to the increase in spike number and eventually grain amount. Nadim et al. (2012) and Jiang et al. (2013) in their respective studies pointed out higher leaf area index and photosynthetic rate in connection with soil applied $\mathrm{Zn}$ at sowing time. Ekiz et al. (1998) noticed significant increase in wheat and other cereals grain yield when $\mathrm{Zn}\left(7 \mathrm{~kg} \mathrm{ha}^{-1}\right)$ was applied in $\mathrm{Zn}$ - deficient soil.

\section{Whole Grain Protein}

In the experiment with soil application of nutrients, $\mathrm{N}$-treatments $\mathrm{N} 2 \mathrm{~N} 160$ and N1N80, resulted in comparatively higher WGP than other $\mathrm{N}$ treatments. Each of these $\mathrm{N}$ - treatments represented different grain yield groups in this study. At N2N160, the grain yield was highest but N1N80 treatment produced lowest yield. At N2N160, the increase in protein with increasing grain yield was supported by increased available $\mathrm{N}$, when $48 \mathrm{~kg} \mathrm{~N} \mathrm{ha}{ }^{-1}$ was supplied at stem elongation since change in protein with change in yield mainly depends on the available $\mathrm{N}$ (Brown et al., 2005). In addition, Brown et al. (2005) illustrated that both increasing and decreasing grain protein with higher grain yield may be due to $\mathrm{N}$ surplus firstly and $\mathrm{N}$ limitation secondly. Similarly, for N1N80, higher protein was associated with lower yield, suggesting the concentration effect (Marschner, 1995). The higher protein concentration may not be the result of sufficient $\mathrm{N}$ but it could be due to the reduction in grain yield by limited available $\mathrm{N}$ and environmental limitation (Fowler, 2003) leading to less dilution.

Late $\mathrm{N}$ application at stem elongation in split $\mathrm{N}$ - treatments enhanced grain protein in comparison with single $\mathrm{N}$ application at sowing (Elhanis et al., 2000; Abedi et al., 2011). When initial $\mathrm{N}$ rate at sowing was sufficient, the split $\mathrm{N}$ applied at stem elongation period assured the increase in both yield and protein. For example, split application of $160 \mathrm{~kg} \mathrm{~N} \mathrm{ha}^{-1}$ (70\% at sowing and $30 \%$ at stem elongation) increased both protein and grain yield. However, split application of $120 \mathrm{~kg} \mathrm{~N} \mathrm{ha}{ }^{-1}$ increased protein concentration but not the yield in comparison to single application of $120 \mathrm{~kg} \mathrm{~N} \mathrm{ha}^{-1}$ at sowing, possibly because of limited availability of initial $\mathrm{N}$ needed for an increase of number of grains per spike (Li et al., 2001).

\section{Iron and Zinc Concentrations in Wheat Grain}

In general, higher concentrations of $\mathrm{Fe}$ and $\mathrm{Zn}$ in grain were recorded for the treatments with lower grain yield and lower concentrations when higher grain yields were achieved. Studies in the past have mentioned that dilution of $\mathrm{Zn}$ and $\mathrm{Fe}$ in wheat grain occurs at increased grain yields (Liu et al., 2006; Gomez-Becerra et al., 2010). Multiple linear regression analysis (Equation 1 and Equation 2) presented a decreasing tendency of $\mathrm{Fe}$ - and $\mathrm{Zn}$ - concentrations in grain with increase in grain yield parameters: TGW and number of grains pot $^{-1}$. Similarly, Zhao et al. (2009) reported that $\mathrm{Zn}$ - concentration of wheat grain correlated negatively with grain yield, but the correlation with grain weight was weak. A positive correlation of $\mathrm{Zn}$ - and Fe- uptake (i.e., total uptake in grain) suggested that higher concentrations of $\mathrm{Zn}$ and $\mathrm{Fe}$ in wheat grain were due to the increased uptake from soil or translocation of $\mathrm{Zn}$ and Fe from vegetative parts to the grain (Cakmak et al., 2010; Kutman et al., 2011).

A multiple linear regression insinuated a dynamic relation among grain $\mathrm{Zn}$ - and Fe- concentrations, their uptake in to grain and grain yield parameters (Marschner, 1995) suggesting that the process was governed by sink-source relation. The negative coefficients for grain yield components suggested that the dilution of $\mathrm{Zn}$ and $\mathrm{Fe}$ in grain was due to combined effect of grain size and the number of grains $\operatorname{pot}^{-1}$ (sink size) as indicated by Sperotto et al. (2013) in rice plant, pointing involvement of factors other than grain (sink strength) only. Other factors could be the availability of metals (Marschner, 1995), for instance, $\mathrm{Zn}$ and Fe during grain filling (Cakmak et al., 2004, 2010; Kutman et al., 2011) or factors contributing dry weight (starch) in grain, which increases the size, and weight of grain (Marschner, 1995; Pleijel et al., 1999).

The application of $30 \%$ higher $\mathrm{Zn}$ and Fe, either separately $\left(\mathrm{Zn}_{\mathrm{s}}+\mathrm{f}\right.$ and $\left.\mathrm{Fe}_{\mathrm{s}}+\mathrm{f}\right)$ or together $\left(\mathrm{Zn}+\mathrm{Fe}_{\mathrm{s}}+\mathrm{f}\right)$, as foliar spray in addition to soil application caused positively significant increase in Zn- (Kutman et al., 2010) and Fe-concentrations in grain (Cakmak et al., 2010; Habib, 2012). For instance, foliar applied $\mathrm{Fe}\left(\mathrm{F}_{\mathrm{s}}+\mathrm{f}\right)$ and $\mathrm{Zn}+\mathrm{Fe}\left(\mathrm{Zn}+\mathrm{Fe}_{\mathrm{s}}+\mathrm{f}\right)$ increased the $\mathrm{Fe}$ - concentration in grain by 34 and $64 \%$ in comparison to growth media applied $\mathrm{Fe}$ and $\mathrm{Zn}+\mathrm{Fe}$, respectively. The respective increases for $\mathrm{Zn}$ were 17 and $46 \%$ for foliar applied $\mathrm{Zn}\left(\mathrm{Zn}_{\mathrm{s}}+\mathrm{f}\right)$ and $\mathrm{Zn}+\mathrm{Fe}\left(\mathrm{Zn}+\mathrm{Fe}_{\mathrm{s}}+\mathrm{f}\right)$. This could be explained by the increased activity of $\mathrm{Zn}$ and $\mathrm{Fe}$ in sources (flag leaf and stem) during grain filling (Cakmak et al., 2010) when additional $\mathrm{Zn}$ and $\mathrm{Fe}$ was supplied at booting. The increase was notably higher for the application of $\mathrm{Zn}+\mathrm{Fe}$ together, similar to the finding of Habib (2012), where Fe and $\mathrm{Zn}$ concentration in wheat grain increased by applying $\mathrm{Zn}$ and Fe together as foliar spray.

\section{Localization of $\mathrm{Zn}$ and $\mathrm{Fe}$ in Wheat Grain}

In this study, concentration map of $\mathrm{Zn}$ and $\mathrm{Fe}$, obtained by MA-XRF and normalized count plots provided by LA-ICP-MS, evidenced the co-existence of both elements, especially at embryo stage and just outside the endosperm and the aleurone layer. This is in accordance with the results obtained using staining technique developed by Cakmak et al. (2010), where the colocalization of protein, $\mathrm{Zn}$, and Fe in embryo was claimed to be due to the co-segregation. Similarly, Kutman et al. (2010) also showed the co- existence of $\mathrm{Zn}$ and protein in a durum wheat grain. Tsuji et al. (2006) used a $\mu$-XRF technique for the elemental mapping of biological materials and found $\mu$-XRF was useful for the analysis of element distribution in grain samples. In elemental map of black wheat and buck or soba wheat by $\mu$-XRF technique, $\mathrm{Zn}$ and Fe were found to be located at either embryo and/or coat of grains (Tsuji et al., 2006). In this study, LA-ICP-MS revealed higher signals for both $\mathrm{Zn}$ and $\mathrm{Fe}$ in the embryo and bran portions, including the aleurone and crease area, with low signals 
in the endosperm (Figure 7). These results are similar to those reported by Cakmak et al. (2010) and Wang et al. (2011), where the distribution of $\mathrm{Zn}$ in wheat grain and its translocation to the endosperm were shown. Based on the decreasing concentration gradient of $\mathrm{Zn}$ from crease area toward endosperm, Cakmak et al. (2010) suggested that $\mathrm{Zn}$ and Fe are translocated and distributed through the crease and then pass in to the endosperm.

To clearly define the location of $\mathrm{Zn}$ and $\mathrm{Fe}$ and their gradients, from bran to endosperm, crease area to endosperm and embryo to endosperm, for instance, the identification of the direction of element supply is essential. For this, the spatial resolution should be higher than in this study. Besides, higher sample numbers and improved sample preparation should ensure improved results, allowing for instance to avoid possible topography/surface effects on element signals.

\section{CONCLUSION}

The rate of $\mathrm{N}$ application at sowing caused an increase in grain and straw yield up to the $\mathrm{N}$ rate of $120 \mathrm{~kg} \mathrm{~N} \mathrm{ha}^{-1}$ and a decrease at higher rate of $\mathrm{N}$. The increase in grain yield was primarily determined by the increase in the number of grains pot $^{-1}$ or number of grains spike ${ }^{-1}$. The split application of $160 \mathrm{~kg} \mathrm{~N} /$ ha increased the grain and straw yield more than split application of $120 \mathrm{~kg} \mathrm{~N} / \mathrm{ha}$. The growth media application of $\mathrm{Fe}$ and $\mathrm{Zn}$ interacted with $\mathrm{N}$ to increase protein, $\mathrm{Zn}$ and Fe concentration in wheat grain. The foliar sprayed $\mathrm{Zn}$ and $\mathrm{Fe}$ at booting stage of wheat significantly increased the whole grain protein, total uptake and concentration of $\mathrm{Fe}$ and $\mathrm{Zn}$ in grain.

MA-XRF and LA-ICP-MS results indicated the co-localization of $\mathrm{Zn}$ and $\mathrm{Fe}$ in grain especially in the embryo and the aleurone. LA-ICP-MS also indicated higher concentration of $\mathrm{Zn}$ and Fe in the crease area and lower in the endosperm, indicating that $\mathrm{Zn}$ and Fe could translocate into the endosperm (the common source of flour in daily food) via crease tissue.

\section{REFERENCES}

Abedi, T., Alemzadeh, A., and Kazemeini, S. A. (2011). Wheat yield and grain protein response to nitrogen amount and timing. Aust. J. Crop Sci. 5, 330-336.

Aciksoz, B. S., Yazicici, A., Ozturk, L., and Cakmak, I. (2011). Biofortification of wheat with iron through soil and foliar application of nitrogen and iron fertilizers. Plant Soil 349, 215-225. doi: 10.1007/s11104-0110863-2

Alfeld, M., Janssens, K., Dik, J., Nolf, W., and van der Snickt, G. (2011). Optimization of mobile scanning macro-XRF systems for the in situ investigation of historical paintings. J. Anal. At. Spectrom. 26, 899-909. doi: $10.1039 / \mathrm{c0ja00257g}$

Barunawati, N., Giehl, R. F. H., Bauer, B., and von Wiren, N. (2013). The influence of inorganic nitrogen fertilizer forms on micronutrient retranslocation and accumulation in grains of winter wheat. Front. Plant Sci. 4:320. doi: 10.3389/ fpls.2013.00320

Bremner, J. M., and Mulvaney, C. S. (1982). "Nitrogen-total," in Methods of Soil Analysis, Part 2, Chemical and Microbiological Properties, 2nd Edn, eds A. L. Miller and D. R. Keeney (Madison, WI: American Society of Agronomy), 595-624.

\section{AUTHOR CONTRIBUTIONS}

BS: planning of experiment, supervision of student, and writing of the manuscript. YT: conduction of the whole experiment, preparation of samples, and thesis writing for his master degree. OL: assitance in the planning, sample preparation, localization studies, and reading of the manuscript. SC: running of LA-ICPMS and MA-XRF studies and reading of the manuscript. KJ: assistance in LA-ICPMS and MA-XRF studies.

\section{FUNDING}

The research part of this master study was financed by the project "Mineral Improved Food and Feed Crops for Human and Animal Health" (Project No. 332160UA) and by a grant from the Norwegian Ministry of Foreign Affairs under the Program for Higher Education, Research and Development (HERD) in Western Balkan. The financial assistance for conducting this study is gratefully acknowledged. We also acknowledge the assistance by CERAD: this study has been funded by the Norwegian Research Council through its Centre of Excellence (CoE) funding scheme (Project No. 223268/F50). This research was supported by the Hercules Foundation (Brussels, Belgium) under grant AUHA09004 and FWO (Brussels, Belgium) Project Nos. G.0C12.13 and G.01769.09.

\section{ACKNOWLEDGMENTS}

We wish to thank Matthias Alfeld and Kevin Hellemans for their precious support in data interpretation and measurements by means of MA-XRF and LA-ICPMS, respectively. This manuscript is based on Mr. Timsina's thesis and that this thesis is the only medium this content has appeared in and that the publication of this content is in line with the policy of the Norwegian University of Life Sciences.

Brown, B., Westcott, M., Christensen, N., Pan, B., and Starck, J. (2005). Nitrogen Management for Hard Wheat Protein Enhancement. Oregon, DC: PNW, 578.

Cakmak, I., and Engels, C. (1999). "Role of mineral nutrients in photosynthesis and yield formation," in Mineral Nutrition of Crops: Mechanisms and Implications, ed. Z. Rengel (New York, NY: The Haworth Press), 14-168.

Cakmak, I. (2002). Plant nutrition research: priorities to meet human needs for food in sustainable ways. Plant Soil 247, 3-24. doi: 10.1023/A:10211945 11492

Cakmak, I., Kalayci, M., Kaya, Y., Torun, A. A., Aydin, N., Wang, Y., et al. (2010). Biofortification and localization of zinc in wheat grain. J. Agric. Food Chem. 58, 9092-9102. doi: 10.1021/jf101197h

Cakmak, I., Torun, A., Millet, E., Feldman, M., Fahima, T., Korol, A., et al. (2004). Triticum dicoccoides: an important genetic resource for increasing zinc and iron concentration in modern cultivated wheat. Soil Sci. Plant Nutr. 50, 1047-1054. doi: 10.1080/00380768.2004.10408573

Ekiz, H., Bagci, S. A., Kiral, A. S., Eker, S., Gültekin, I., Alkan, A., et al. (1998). Effects of zinc fertilization and irrigation on grain yield and zinc concentration of various cereals grown in zinc-deficient calcareous soils. J. Plant Nutr. 21, 2245-2256. doi: 10.1080/01904169809365558 
Elhanis, S., GracÍa del Moral, L. F., Marthos, V., and And Rharrahti, Y. (2000). "Relationship between some quality traints and yield of durum wheat under southern Spain conditions," in Durum Wheat Improvement in the Mediterranean Region, eds C. Royo, M. Nachit, N. Di Fonzo and J. L. Nrans (Zaragoza: CIHEAM), 529-531.

Erenoglu, E. B., Kutman, U. B., Ceylan, Y., Yildiz, B., and Cakmak, I. (2011). Improved nitrogen nutrition enhances root uptake, root-to-shoot translocation and remobilization of zinc $\left({ }^{65} \mathrm{Zn}\right)$ in wheat. New Phytol. 189, 438-448. doi: 10.1111/j.1469-8137.2010.03488.x

Fowler, D. B. (2003). Crop nitrogen demand and grain protein concentration of spring and winter wheat. Agron. J. 95, 260-265. doi: 10.2134/agronj2003.0260

Gomez-Becerra, H. F., Yazici, A., Ozturk, L., Budak, H., Peleg, Z., Morgounov, A., et al. (2010). Genetic variation and environmental stability of grain mineral nutrient concentrations in Triticum dicoccoides under five environments. Euphytica 171, 39-52. doi: 10.1007/s10681-009-9987-3

Graham, R. D., Welch, R. M., and Bouis, H. E. (2001). Addressing micronutrient malnutrition through enhancing the nutritional quality of staple foods: principles, perspectives and knowledge gaps. Adv. Agron. 70, 77-142. doi: 10.1016/S0065-2113(01)70004-1

Habib, M. (2012). Effect of supplementary nutrition with Fe, Zn chelates and urea on wheat quality and quantity. Afr. J. Biotechnol. 11, 2661-2665.

Haslett, B. S., Teid, R. J., and Rengel, Z. (2001). Zinc mobility in wheat: uptake and distribution of zinc applied on leaves or roots. Ann. Bot. 87, 379-389. doi: 10.1006/anbo.2000.1349

Hotz, C., and Brown, K. H. (2004). Assessment of the risk of zinc deficiency in populations and options for its control. Food Nutr. Bull. 25, S91-S202.

ISO (2009). Food Products - Determination of the Total Nitrogen Content by Combustion According to the Dumas Principle and Calculation of the Crude Protein Content - Part 2: Cereals, Pulses and Milled Cereal Products. Geneva: ISO, 1-25.

Jiang, L., Zhang, D., Song, F., Zhang, X., Shao, Y., and Li, C. (2013). Effects of zinc on growth and physiological characters of flag leaf and grains of winter wheat after anthesis. Adv. J. Food Sci. Technol. 5, 571-577. doi: 10.19026/ajfst.5.3129

Kutman, U. B., Kutman, Y., Ceylan, Y., Ova, E. A. B., and Cakmak, I. (2012). Contribution of root uptake and remobilization to grain zinc accumulation in wheat depending on post-anthesis zinc availability and nitrogen nutrition. Plant Soil 361, 177-187. doi: 10.1007/s11104-012-1300-x

Kutman, U. B., Yildiz, B., and Cakmak, I. (2010). Improved nitrogen status enhances zinc and iron concentrations both in the whole grain and the endosperm fraction of wheat. J. Cereal Sci. 53, 118-125. doi: 10.1016/j.jcs.2010. 10.006

Kutman, U. B., Yildiz, B., and Cakmak, I. (2011). Effect of nitrogen on uptake, remobilization and partitioning of zinc and iron throughout the development of durum wheat. Plant Soil 342, 149-164. doi: 10.1007/s11104-010-0679-5

Li, C., Cao, W., and Dai, T. (2001). Dynamic characteristics of floret primordium development in wheat. Field Crops Res. 71, 71-76. doi: 10.1016/S0378-4290(01) 00144-7

Liu, Z. H., Wang, H. Y., Wang, X. E., Zhang, G. P., Chen, P. D., and Liu, D. J. (2006). Genotypic and spike positional difference in grain phytase activity, phytate, inorganic phosphorus, iron, and zinc contents in wheat (Triticum aestivum L.). J. Cereal Sci. 44, 212-219. doi: 10.1016/j.jcs.2006.06.001

Marino, S., Tognetti, R., and Alvino, A. (2009). Crop yield and grain quality of emmer populations grown in central Italy, as affected by nitrogen fertilization. Eur. J. Agron. 31, 233-240. doi: 10.1016/j.eja.2009.08.002

Marschner, H. (1995). Mineral Nutrition of Higher Plants. London: Academic Press.

Mutangadura, G. B. (2004). World Health Report 2002: Reducing Risks, Promoting Healthy Life. Geneva: World Health Organization.

Nadim, M. A., Awan, I. U., Baloch, M. S., Khan, E. A., Naveed, K., and Khan, M. A. (2012). Response of wheat (Triticum aestivum L.) to different micronutrients and their application methods. J. Anim. Plant Sci. 22, 113-119.

Nowack, B., Schwyzer, I., and Schulin, R. (2008). Uptake of $\mathrm{Zn}$ and Fe by wheat (Triticum aestivum var. Greina) and transfer to the grain in the presence of chelating agents (Ethylenediaminedisuccinic acid and
Ethylenediaminetetraacetic acid. J. Agric. Food Chem. 56, 4643-4649. doi: $10.1021 / \mathrm{jf} 800041 \mathrm{~b}$

OECD (1984). OECD Guidelines for Testing of Chemicals. Paris: OCED.

Ozturk, L., Altintas, G., Erdem, H., Gokmen, O. O., Yazici, A., and Cakmak, I. (2009). "Localization of iron, zinc, and protein in seeds of spelt (Triticum aestivum ssp. Spelta) genotypes with low and high protein concentration," in Proceedings of the International Plant Nutrition Colloquium XVI, Department of Plant Sciences, Davis, CA.

Peleg, Z., Saranga, Y., Yazici, M. A., Fahima, T., Ozturk, L., and Cakmak, I. (2008). Grain zinc, iron and protein concentrations and zinc-efficiency in wild emmer wheat under contrasting irrigation regimes. Plant Soil 306, 57-67. doi: 10.1007/ s11104-007-9417-z

Persson, D. P., deBang, T. C., Pedas, P. R., Kutman, U. B., Cakmak, I., and Andersen, B. (2016). Molecular speciation and tissue compartmentation of zinc in durum wheat grains with contrasting nutritional status. New Phytol. 211, 1255-1263. doi: 10.1111/nph.13989

Pleijel, H., Mortensen, L., Fuhrer, J., Ojanpera, K., and Danielsson, H. (1999). Grain protein accumulation in relation to grain yield of spring wheat (Triticum eastivum L.) grown in open-top chambers with different concentrations of ozone, carbon dioxide and water availability. Agric. Ecosyst. Environ. 72, 265-270. doi: 10.1016/S0167-8809(98)00185-6

Shi, R., Zhang, Y., Chen, X., Sun, Q., Zhang, F., Römheld, V., et al. (2010). Influence of long-term nitrogen fertilization on micronutrient density in grain of winter wheat (Triticum aestivum L.). J. Cereal Sci. 51, 165-170. doi: 10.1016/j.jcs.2009. 11.008

Silspour, M. (2007). The study of $\mathrm{Fe}$ and $\mathrm{Zn}$ effects on quantitative and qualitative parameters of winter wheat and determination of critical levels of these elements in Varamin plain soils. Pajouhesh Sazandegi 76, 123-133.

Sperotto, R. A., Ricachenevsky, F. K., Waldow, V. D. A., Müller, A. L. H., Dressler, V. L., et al. (2013). Rice grain Fe, Mn and Zn accumulation: how important are flag leaves and seed number. Plant Soil Environ. 59, 262-266.

Šramková, Z., Gregová, E., and Šturdik, E. (2009). Chemical composition and nutritional quality of wheat grain. Acta Chim. Slovaca 2, 115-138.

Timsina, Y. N. (2014). Effect of Nitrogen Fertilization on Zinc and Iron Uptake and Yield Components of Wheat. Master thesis, Norwegian University of Life Sciences, As, Akershus, 80.

Tsuji, K., Tsutsumimoto, K., Nakano, K., Tanaka, K., Okhrimovskyy, A., Konishi, Y., et al. (2006). Time-Resolved $\mu$-XRF and Elemental Mapping of Biological Materials. Newtown Square, PA: JCPDS- International Center for Diffraction Data, 296-301.

Velu, G., Ortiz-Monasterio, I., Singh, R. P., and Payne, T. (2011). Variation for grain micronutrients concentration in wheat core-collection accessions of diverse origin. Asian J. Crop Sci. 3, 43-48. doi: 10.3923/ajcs.2011.43.48

Wang, Y. X., Specht, A., and Horst, W. J. (2011). Stable isotope labeling and zinc distribution in grain by laser ablation ICP-MS in an ear culture system reveals zinc transport barriers during grains filling wheat. New Phytol. 189, 428-437. doi: 10.1111/j.1469-8137.2010.03489.x

Zhao, F. J., Su, Y. H., Dunham, S. J., Raxszegi, M., Bedo, Z., McGrath, S. P., et al. (2009). Variation in mineral micronutrient concentrations in grain by wheat lines of diverse origin. J. Cereal Sci. 49, 290-295. doi: 10.1016/j.jcs.2008.11.007

Conflict of Interest Statement: The authors declare that the research was conducted in the absence of any commercial or financial relationships that could be construed as a potential conflict of interest.

Copyright (c) 2018 Singh, Timsina, Lind, Cagno and Janssens. This is an open-access article distributed under the terms of the Creative Commons Attribution License (CC BY). The use, distribution or reproduction in other forums is permitted, provided the original author(s) and the copyright owner are credited and that the original publication in this journal is cited, in accordance with accepted academic practice. No use, distribution or reproduction is permitted which does not comply with these terms. 